\title{
Knowledge of the prison population about sexually transmitted infections
}

\section{Franciele Facco de Carvalho ${ }^{a}$ Elisabete Takedab Eduardo Federighi Baisi Chagas ${ }^{\mathrm{b}, \mathrm{c}}$ Osni Lázaro Pinheiro ${ }^{b}$}

How to cite this article: Carvalho FF, Takeda E, Chagas EFB, Pinheiro OL. Knowledge of the prison population about sexually transmitted infections. Rev Gaúcha Enferm. 2020;41:e20190268. doi: https://doi.org/10.1590/19831447.2020.20190268
Autonomous Researcher. Osvaldo Cruz, São Paulo, Brasil.

¿ Faculdade de Medicina de Marília (FAMEMA), Programa de Mestrado Profissional "Ensino em Saúde". Marília, São Paulo, Brasil.

Universidade de Marilia (UNIMAR). Marilia, São Paulo, Brasil.

\section{ABSTRACT}

Objective: To verify the prison population's knowledge of sexually transmitted infections.

Methods: An illustrated questionnaire was prepared based on the Ministry of Health's information booklet to provide information about sexually transmitted infections and applied to a sample of the prison population (PP) $(n=158)$. This is a descriptive and crosssectional research conducted in 2017 in one of the penitentiaries in the western region of the state of São Paulo.

Results: The study sample presented both correct knowledge and misconceptions regarding the identification, prevention, treatment and ways of transmission of these infections. Among these aspects, the identification of these infections raised the most doubts, especially about those that produce penile lesions.

Conclusion: The data obtained in the study reinforces the need for greater investments in the knowledge of sexually transmitted infections in the prison setting. They should focus on educational activities contextualized to the profile of this population: young adults with low education and little access to information.

Keywords: Sexually transmitted diseases. Primary prevention. Prisoners. Health promotion.

\section{RESUMO}

Objetivo: Verificar o conhecimento da população privada de liberdade sobre as infecções sexualmente transmissíveis.

Métodos: Foi elaborado um questionário ilustrado, pautado no álbum seriado do Ministério da Saúde, abordando informações sobre infeções sexualmente transmissíveis e aplicada para uma amostra da PPL ( $n=158)$. Trata-se de uma pesquisa de natureza descritiva, de corte transversal, realizada em 2017, em uma das penitenciárias da região Oeste do estado de SP.

Resultados: A amostra participante do estudo apresentou acertos e equívocos em relação à identificação, prevenção, tratamento e formas de transmissão dessas infecções. Dentre estes aspectos, a identificação dessas infecções foi o que mais gerou dúvidas, principalmente as que produzem lesões penianas.

Conclusão: Em conjunto, os dados obtidos no estudo reforçam a necessidade de maiores investimentos em relação às infeções sexualmente transmissíveis no ambiente carcerário. Esta atenção perpassa por atividades educativas que deverão estar contextualizadas ao perfil desta população, adultos jovens, com baixa escolaridade e pouco acesso às informaç̧ões.

Palavras-chave: Doenças sexualmente transmissíveis. Prevenção primária. Prisioneiros. Promoção da saúde.

\section{RESUMEN}

Objetivo: verificar el conocimiento de la población privada de la libertad (PPL) sobre las infecciones de transmisión sexual.

Métodos: se elaboró un cuestionario ilustrado, basado en el folleto informativo del Ministerio de Salud, que abordó información sobre infecciones de transmisión sexual y se aplicó a una muestra de PPL ( $n=158)$. Se trata una investigación descriptiva y de corte transversal realizada en 2017 en uno de los centros penitenciarios en la región occidental del estado de SP.

Resultados: la muestra del estudio presentó conceptos correctos y erróneos con respecto a la identificación, prevención, tratamiento y formas de transmisión de estas infecciones. Entre estos aspectos, la identificación de estas infecciones generó la mayor cantidad de dudas, especialmente sobre aquellas que producen lesiones en el pene.

Conclusión: en conjunto, los datos obtenidos en el estudio refuerzan la necesidad de mayores inversiones en relación con las infecciones de transmisión sexual en el entorno penitenciario. Este esfuerzo se realiza a través de actividades educativas que deberían contextualizarse al perfil de esta población: adultos jóvenes con bajo nivel de escolaridad y poco acceso a la información.

Palabras clave: Enfermedades de transmisión sexual. Prevención primaria. Prisioneros. Promoción de la salud. 


\section{口INTRODUCTION}

Brazil is the fifth most populous country on the planet and has the fourth largest prison population in the world, with the sixth highest prison rate for every 100 thousand inhabitants ${ }^{(1)}$. According to data from the National Penitentiary Information Survey (INFOPEN) in 2017, the Brazilian prison population totaled 726,354 individuals $s^{(2)}$.

However, the number of prison units in the country is not enough to meet this demand, leading to prison overcrowding with repercussions on the quality of life of this population, who should be deprived only of liberty but also end up losing a series of rights, including access to health, one of the basis of the Unified Health System (Sistema Único de Saúde, SUS)(3).

The Brazilian Federal Constitution of 1988 understood that the health of citizens was a duty of the State, which also contemplated the prison population (PP); however, this principle of universality for the PP was not yet fully available at that time. The creation of the National Health Plan in the Penitentiary System (Plano Nacional de Saúde no Sistema Penitenciário, PNSSP) in 2002 improved PP's access to the health system, which was further expanded with the creation in 2014 of the National Comprehensive Health Care Policy for the Prison Population in the Prison System (Política Nacional de Atenção Integral à Saúde das Pessoas Privadas de Liberdade no Sistema Prisional, PNAISP) ${ }^{(1)}$.

Health care for citizens living in prison units is reduced, and generally involves actions aimed at controlling Hypertension, Diabetes, Sexually Transmitted Infections (STIs)/AIDS, Tuberculosis, Mental and Oral Health care, immunization, and general assistance ${ }^{(1)}$.

However, despite these initiatives, the conditions in prison facilities still make prisoners vulnerable to, for instance, infectious and sexually transmitted diseases. This population usually lives in an overcrowded prison system, in precarious sanitary conditions, with the consumption of illicit drugs and unprotected sexual activities. Combined with these factors, effective initiatives for educational and health actions are also absent, making the prison environment an inhospitable scenario for health ${ }^{(3)}$.

Among the health risks that the PP is exposed to, the unhealthy conditions of prison environments make this group vulnerable to Sexually Transmitted Infections (STIS). The absence of effective educational projects for the prevention of STIs in these scenarios increases this vulnerability ${ }^{(4)}$.

In the health sector, vulnerability involves the conditions faced by the individual or social group as to decide on their risk situation for a certain disease. This concept can be influenced by individual, family, cultural, biological, social, political and economic factors, since vulnerability seeks the particularization of relationships, and not the generalization of inferences ${ }^{(4-5)}$.

In the context of STIs, the prison population deserves special attention. It is a population with high vulnerability since factors such as the absence of freedom, overcrowding in prison units, risky sexual behaviors and the lack of effective health prevention and promotion policies favor the spread of STIS ${ }^{(6)}$.

A study carried out in the state of Pernambuco reinforces that the incidence of STIS/AIDS in inmates is twice that of the national population, due to the incarceration that favors homosexual relationships without the use of condoms, in addition to the sexual violence practiced by other inmates and sharing razor blades and needles ${ }^{(6)}$.

According to estimates by the World Health Organization, more than one million people worldwide acquire STIs per day. Taking into account syphilis acquired in 2018,158,051 cases were reported and there was an increase of $28.3 \%$ in detection, which went from 59.1 to 75.8 cases/100,000 inhabitants. These data are mainly due to not using condoms and to not adhering to the treatment, which is painful and prolonged, making it difficult to finish the treatment. Another important aspect that may justify the increase in the number of cases is the expansion of the testing process in the population ${ }^{(7)}$.

Syphilis is an infectious bacterial disease caused by Treponema pallidum, transmitted through sexual intercourse. If the treatment is not carried out properly, the disease may evolve due to the bacteria spreading through the system, reaching the skin and organs like the heart, the liver and the central nervous system. An important aspect is that in primary syphilis, lesions can disappear, even without treatment. This remission does not mean that the patient was cured and this infection may progress to other stages, attacking other organs $s^{(8)}$.

It is estimated that the prevalence of infection by the Human Immunodeficiency Virus (HIV) and AIDS in prisons varies from 3 to $16 \%$, showing the greatest impact among the STIs. However, these values may be underestimated, since many prisoners are HIV positive, but are not diagnosed ${ }^{(9)}$.

In the context of viral hepatitis, it is estimated that approximately 657 thousand individuals have the Hepatitis C virus in Brazil, with the majority of people infected with chronic viral hepatitis unaware of their diagnosis, increasing the risk of transmission of these infections ${ }^{(10)}$.

Despite the evolution in diagnosis methods and treatment, there is still a certain lack of knowledge on the part of the population about STIs, especially in prisons. This aspect is of paramount importance, since the knowledge of the health 
problem and the repercussions in the organism can represent a determining factor for the prevention of the disease ${ }^{(4)}$.

In this context, this work presents the following research question: What information does the PP has about the main STIs that are present in the prison setting? The answer to this question may identify the aspects related to the vulnerability of this population to STIS, thus guiding the implementation of prevention and health promotion strategies.

Exactly in this aspect lies the objective of this study, that is, to verify the information that the PP has about Sexually Transmitted Infections.

\section{METHOD}

This paper is linked to the master's thesis entitled: "Health education as a tool for the prevention of sexually transmitted infections in the prison population". This is a descriptive and cross-sectional research ${ }^{(11)}$.

It was approved by the Penitentiary Administration Office of the state of São Paulo (Secretaria de Administração Penitenciária do Estado de São Paulo, SAP-SP) and by the Ethics Committee for Research (Comitê de Ética em Pesquisa, CEP) involving Human Beings of the Medical School of Marilia (Faculdade de Medicina de Marília, FAMEMA), receiving the Certificate of Presentation for Ethical Approval (Certificado de Apresentação para Apreciação Ética, CAAE) No. 80428717.6.0000.5413.

The research was carried out in one of the prisons in the western region of the state of São Paulo. In August 2017, the year in which this study was carried out, this prison unit registered a population of 1,141 male prisoners. It should be noted that this unit has the capacity to accommodate 844 inmates, and the sentence is served without parole.

To verify the PP's information about STIs, an illustrated questionnaire was prepared by the research group responsible for this study, with the support of invited professionals in the areas of infectious diseases and urology. One of these professionals also had previous experience working in a prison setting.

The STIs addressed were those with the most evident signs and symptoms and that help in their identification. All images used were based on the Ministry of Health'Sexually Transmitted Infection Information Booklet ${ }^{(12)}$.

The questionnaire showed one image depicting gonorrhea (questions 1 to 4) and two images about syphilis, one for the primary form and the other for the secondary form (questions 5 to 8). An image was then presented for the human papillomavirus (HPV) (questions 9 to 12) and for genital herpes (question 13). The images were followed by questions with four alternative answers, one of which was the "I don't know"option. The questionnaires were distributed to the PP in the prison sector where they study and/or work.

The sample size was estimated to analyze the distribution of proportion greater than $50 \%$ of correct answers by the Chisquare proportion test. Considering a type I error margin (a) of $1 \%$, a study power of $90 \%$, and a mean effect size of 0.15 , the minimum sample size was of 143 sampling elements. The sample size was estimated using the $G^{*}$ Power software, version 3.1.9.2 (Franz Faul, Universität Kiel, Germany). Taking into account a possible sample loss of 10\%, the sample size was 158 sampling elements.

After checking the inclusion criteria, the subjects were randomly selected, featuring a probability sample. The following inclusion criteria were considered: prisoners; with a sentence of more than three years in prison without parole; being literate, and studying and/or working in the prison unit. Illiterate individuals who do not work or study were not included in the survey. The entire PP signed the Free and Informed Consent Form and no individual refused to participate in the research.

The qualitative variables are described by the distribution of relative (\%) and absolute (N) frequencies. To analyze the difference in the distribution of proportion between the categories, the Chi-square test was used. The level of significance adopted was $5 \%(p \leq 0.05)$. The data was analyzed using the SPSS software, version 19.0.

\section{$\square$ RESULTS}

All the participants were male, as the prison unit studied only houses this population. There was a predominance of individuals belonging to the age group between 20 and 29 years old who did not finish elementary and middle school (32.9\%) and high school (46.8\%) (Table 1).

Questions 1 to 4 (gonorrhea) asked the PP to identify the disease and the forms of prevention, treatment and transmission. In all of these items, the number of correct answers was significantly higher than the number of incorrect answers $(p<0.001-$ Table 2). Among the aspects evaluated, the identification of the disease was the most difficult question, with approximately $26 \%$ of incorrect answers, and prevention represented the item with the lowest level of difficulty (5.1\%).

Urinary infection and syphilis were the options selected by approximately $18 \%$ of the individuals who were unable to identify image 1 of the questionnaire as a case of gonorrhea. In addition, around 8\% of them acknowledge they were unaware of the STI shown in image 1.

Regarding the prevention of gonorrhea, although they knew about the importance of using condoms, the contraceptive pill was mentioned by three participants, and 
Table 1 - Characterization of the PP by age and schooling level $(n=158)$

\begin{tabular}{lcccc} 
Age & Incomplete Elementary (\%) & Incomplete Secondary (\%) & Complete Secondary (\%) & Total (\%) \\
\hline $18-19$ & $6(3.8)$ & $13(8.2)$ & $1(0.63)$ & $20(12.6)$ \\
\hline $20-29$ & $32(20.2)$ & $52(32.9)$ & $14(8.8)$ & $98(62)$ \\
\hline $30-39$ & $7(4.4)$ & $8(5)$ & $15(9.5)$ & $30(19)$ \\
\hline $40-49$ & $6(3.8)$ & $1(0.6)$ & $2(1.2)$ & $9(5.7)$ \\
\hline $50-59$ & $1(0.6)$ & $0(0)$ & $0(0)$ & $1(0.6)$ \\
\hline
\end{tabular}

Source: Research data, 2017.

five individuals did not know the best way to avoid this STI (Table 2).

It was also possible to verify that $10 \%$ of them struggle to give the right answer about the transmission of gonorrhea, answering that the use of towels and underwear could be associated with the transmission.

Although the treatment of gonorrhea requires the systemic use of antibiotics prescribed by a physician, $18 \%$ of this sample was unaware of the treatment.

Syphilis was addressed in questions 5 to 8 (Table 2). The identification and treatment of this STI were the aspects with the most difficulties, and $45 \%$ did not identify the image that represented syphilis. There was a misunderstanding by $62 \%$ of the PP regarding the identification of the disease and by $53 \%$ regarding the treatment. The PP found it easier to answer questions about the ways of preventing and spreading syphilis.

Despite the difficulty in identifying syphilis lesions, their prevention was correctly identified. Even so, the participants marked wrong forms of prevention, such as the withdrawal method.

The appropriate treatment for syphilis also caused difficulties among the sample of the PP, as they marked options such as the use of dressings in the lesions (7\%) and also the use of condoms (25.3\%). A portion of the PP did not know how to indicate the correct treatment (22.8\%).

Regarding transmission, options like handshakes and using towels were mistakenly marked by $12 \%$ of the participants, and 13\% did not know how to answer the question.

HPV, which represents a global health problem, was also included in the questionnaire used with the PP (questions 9 to 12 - Table 2). Although in every question related to HPV there was a predominance of correct answers, it is worth noting that the PP struggles to identify this STI when looking at the image (35.4\%), as well as to indicate the appropriate treatment (32.3\%).

Also worthy of attention is the fact that, among the STIs described in the questionnaire, HPV infection was the one that the PP had the most difficulty in identifying its forms of prevention (22.2\%). Although the majority of the PP correctly identified the injury caused by HPV, they confused it with syphilis, marked by approximately $8 \%$ of the participants. In addition, around $22 \%$ of the sample stated that they did not know the lesion shown in the image.

The form of prevention was correctly identified by the majority, although approximately 23\% did not know how to prevent HPV or marked inappropriate prevention options, such as the use of the withdrawal method and sexual lubricants before intercourse. The treatment was correctly identified by the majority of the population, but the local use of lubricants (5.1\%) and condoms (10.1\%) were mistakenly identified as treatment options. In addition, $17.7 \%$ were unaware of the treatment.

Handshakes and the use of towels and underwear were marked by approximately $9 \%$ of the individuals, and around this same proportion did not know how the disease is acquired.

The last question addressed the identification of genital herpes, with a predominance of correct answers by the PP $(p<0.001)$; however, it should be noted that there were difficulties in identifying this STI in 36\% of the sample, a value very close to that found for HPV (Table 2). In addition, the participants confused these injuries with those caused by syphilis (10.8\%). The total lack of knowledge on the part of the study participants about this STI was also high and the "I don't know" option was marked by $24.1 \%$. 
Table 2 - Distribution of the items marked by the prisoners in the questionnaire on sexually transmitted infections

\begin{tabular}{|c|c|c|c|c|}
\hline Question & Alternatives & $\mathbf{N}$ & $\%$ & p-value \\
\hline \multirow{4}{*}{$\begin{array}{l}\text { 1-Gonorrhea } \\
\text { (Identification) }\end{array}$} & Incorrect - Syphilis & 16 & 10.1 & \multirow{4}{*}{$<0.001 *$} \\
\hline & Incorrect - Urinary Infection & 13 & 8.2 & \\
\hline & Correct - Gonorrhea & 116 & 73.4 & \\
\hline & Don't know & 13 & 8.2 & \\
\hline \multirow{4}{*}{$\begin{array}{l}\text { 2-Gonorrhea } \\
\text { (Prevention) }\end{array}$} & Incorrect - Using a birth control pill & 3 & 1.9 & \multirow{4}{*}{$<0.001 *$} \\
\hline & Incorrect - Using lubricant before sexual intercourse & 0 & 0.0 & \\
\hline & Correct - Using a condom during sexual intercourse & 150 & 94.9 & \\
\hline & Don't know & 5 & 3.2 & \\
\hline \multirow{4}{*}{$\begin{array}{l}\text { 3-Gonorrhea } \\
\text { (Treatment) }\end{array}$} & Incorrect - Applying ointments to the lesions for a week & 5 & 3.2 & \multirow{4}{*}{$<0.001 *$} \\
\hline & Incorrect - Two weeks without sexual intercourse & 6 & 3.8 & \\
\hline & Correct - Ask the doctor to prescribe antibiotic & 129 & 81.6 & \\
\hline & Don't know & 18 & 11.4 & \\
\hline \multirow{4}{*}{$\begin{array}{l}\text { 4-Gonorrhea } \\
\text { (Transmission) }\end{array}$} & Incorrect - By handshakes & 0 & 0.0 & \multirow{4}{*}{$<0.001^{*}$} \\
\hline & Incorrect - Using someone else's towels/underwear & 10 & 6.3 & \\
\hline & Correct - By vaginal, oral and anal sex & 141 & 89.2 & \\
\hline & Incorrect - Don't know & 7 & 4.4 & \\
\hline \multirow{4}{*}{$\begin{array}{l}\text { 5-Syphilis } \\
\text { (Identification) }\end{array}$} & Incorrect - Genital Warts & 72 & 45.6 & \multirow{4}{*}{$<0.001^{*}$} \\
\hline & Incorrect - AIDS (HIV) & 7 & 4.4 & \\
\hline & Correct - Syphilis & 58 & 36.7 & \\
\hline & Don't know & 21 & 13.3 & \\
\hline \multirow[t]{4}{*}{$\begin{array}{l}\text { 6-Syphilis } \\
\text { (Prevention) }\end{array}$} & $\begin{array}{l}\text { Incorrect - Having sex, but not ejaculating inside } \\
\text { the partner }\end{array}$ & 3 & 1.9 & \multirow{4}{*}{$<0.001 *$} \\
\hline & Incorrect - Using lubricant before sexual intercourse & 3 & 1.9 & \\
\hline & Correct - Using a condom during sexual intercourse & 141 & 89.2 & \\
\hline & Don't know & 11 & 7.0 & \\
\hline \multirow{4}{*}{$\begin{array}{l}\text { 7-Syphilis } \\
\text { (Treatment) }\end{array}$} & Incorrect - Washing the lesion with hydrogen peroxide & 11 & 7.0 & \multirow{4}{*}{$<0.001 *$} \\
\hline & Incorrect - Using a condom during sexual intercourse & 40 & 25.3 & \\
\hline & $\begin{array}{l}\text { Correct - Ask the doctor to prescribe } \\
\text { penicillin (Benzathine }{ }^{\circledR} \text { ) }\end{array}$ & 71 & 44.9 & \\
\hline & Don't know & 36 & 22.8 & \\
\hline \multirow{4}{*}{$\begin{array}{l}\text { 8-Syphilis } \\
\text { (Transmission) }\end{array}$} & Incorrect - By handshakes & 1 & 0.6 & \multirow{4}{*}{$<0.001^{*}$} \\
\hline & Incorrect - Using someone else's towels/underwear & 18 & 11.4 & \\
\hline & Correct - By vaginal, oral and anal sex & 118 & 74.7 & \\
\hline & Don't know & 21 & 13.3 & \\
\hline
\end{tabular}


Table 2 - Cont.

\begin{tabular}{|c|c|c|c|c|}
\hline Question & Alternatives & $\mathbf{N}$ & $\%$ & p-value \\
\hline \multirow{4}{*}{$\begin{array}{l}\text { 9-HPV } \\
\text { (Identification) }\end{array}$} & Incorrect - Syphilis & 13 & 8.2 & \multirow{4}{*}{$<0.001^{*}$} \\
\hline & Incorrect - AIDS (HIV) & 10 & 6.3 & \\
\hline & Correct - Genital Warts (HPV) & 99 & 62.7 & \\
\hline & Don't know & 36 & 22.8 & \\
\hline \multirow[t]{4}{*}{$\begin{array}{l}\text { 10-HPV } \\
\text { (Prevention) }\end{array}$} & $\begin{array}{l}\text { Incorrect - Having sex, but not ejaculating inside } \\
\text { the partner }\end{array}$ & 5 & 3.2 & \multirow{4}{*}{$<0.001^{*}$} \\
\hline & Incorrect - Using lubricant before sexual intercourse & 6 & 3.8 & \\
\hline & Correct - Using a condom during sexual intercourse & 122 & 77.2 & \\
\hline & Don't know & 25 & 15.8 & \\
\hline \multirow{4}{*}{$\begin{array}{l}\text { 11-HPV } \\
\text { (Treatment) }\end{array}$} & Incorrect - Applying ointment to the lesion & 8 & 5.1 & \multirow{4}{*}{$<0.001 *$} \\
\hline & Incorrect - Using a condom during sexual intercourse & 16 & 10.1 & \\
\hline & Correct - Medical care for cauterization & 106 & 67.1 & \\
\hline & Don't know & 28 & 17.7 & \\
\hline \multirow{4}{*}{$\begin{array}{l}\text { 12-HPV } \\
\text { (Transmission) }\end{array}$} & Incorrect - By handshakes & 2 & 1.3 & \multirow{4}{*}{$<0.001^{*}$} \\
\hline & Incorrect - Using someone else's towels and underwear & 12 & 7.6 & \\
\hline & Correct - By sexual intercourse & 130 & 82.3 & \\
\hline & Don't know & 14 & 8.9 & \\
\hline \multirow{4}{*}{$\begin{array}{l}\text { 13-Herpes } \\
\text { (Identification) }\end{array}$} & Incorrect - Syphilis & 17 & 10.8 & \multirow{4}{*}{$<0.001^{*}$} \\
\hline & Incorrect - Urinary Infection & 6 & 3.8 & \\
\hline & Correct - Genital Herpes & 97 & 61.4 & \\
\hline & Don't know & 38 & 24.1 & \\
\hline
\end{tabular}

Source: Research data, 2017.

Note: * $p$-value $\leq 0.05$, significant difference of the distribution of proportion among the schooling categories using the chi-square test.

\section{DISCUSSION}

This study verified the PP's knowledge about a very recurrent theme in discussions about the health needs of this population: sexually transmitted infections. The use of images to depict the STIs offered a more real context for the participants.

In general, the sociodemographic data of the individuals who participated in this study did not differ from those present in the Brazilian prison population. Generally, this population is composed of young individuals between 18 and 24 years of age, who represent one third of all people in prison, with lower a schooling level than the general population ${ }^{(1)}$.
The questionnaire showed that some of the participants' answers were correct and others were incorrect regarding the identification, prevention, treatment and forms of transmission of these infections. Among these aspects, the identification of the STIs was the factor that generated the most doubts.

Few individuals had difficulties in identifying an important and well-characterized STI, gonorrhea. The image used in the questionnaire portrayed a classic gonococcal urethritis and, although most of the participants identified it correctly, the results must be looked at carefully, since the other individuals, who marked incorrect options, may, due to lack of knowledge, constitute a more vulnerable population to acquire and spread this STI. 
However, incidentally there were difficulties for the study population to identify the diseases that are manifested through penile lesions, such as syphilis, HPV and genital herpes.

Regarding syphilis, the illustrated questionnaire showed images of both the primary lesion on the penis, as well as skin lesions, located in the palmoplantar regions. However, the participants had difficulties in associating syphilis to both images.

The skin lesions presented may have raised doubts with respect to other diseases that also manifest on the skin. Mainly, this may have occurred with those who did not know the answer. The PP's difficulty in identifying this STI is a disturbing aspect, since the number of syphilis cases is increasing in Brazil and the prison population is also considered vulnerable to its transmission ${ }^{(13)}$.

The results showed that prisoners often have difficulties in making the association between the type of lesion and the corresponding STI and, in addition, they also did not identify the appropriate form of prevention. Thus, it is presumed that sexual intercourse during the period when the lesion is not present makes the problem even more complex.

The results obtained in this study corroborate the data found in a research carried out with a prison population in the state of Rondônia, in which it was also possible to note the lack of information on the part of the prisoners about syphilis, especially regarding its diagnosis, signs, symptoms and forms of transmission. This information was obtained from the medical records of the individuals who underwent the quick test for syphilis, mostly men ${ }^{(4)}$.

HPV is an STI that causes doubts in the population, promoting misconceptions that can cause negligence regarding its prevention. Among the aspects neglected by the population, the lack of knowledge about the existence of a vaccine for this STI stands out which, despite being widely disclosed, has not yet reached the whole society ${ }^{(14)}$.

In general, the studies related to the knowledge of the prison population about HPV are conducted in prisons for women. In this sense, a study carried out with incarcerated women showed that the prior knowledge of this population about HPV was restricted to the association of this STI with cervical cancer and to the need to do the preventive exam. However, the knowledge of this population had no impact on aspects such as the transmission cycle, the treatment and other forms of prevention ${ }^{(6)}$.

In another study carried out outside the prison context, it was found that most of the men and women interviewed were unaware of this STI; some factors associated with this lack of knowledge included being a man, depending on public health services and low schooling ${ }^{(15-16)}$. It is noteworthy that these factors were the same as those found in this survey, but aggravated by the incarceration, which makes access to information even more difficult.

The image used in the data collection instrument portrayed a classic case of genital herpes; however, the study sample had difficulties in identifying this lesion and in some cases associated syphilis to the image. It should be noted that, although the lesions of these two STIs are different, the literature highlights the need for a differential diagnosis between syphilis and genital herpes.

The occurrence of genital herpes in individuals with HIV/AIDS is very common and can be manifested by large ulcers, with no chance of healing spontaneously. It is relevant to highlight that HIV/AIDS is a very frequent reality in prison settings ${ }^{(10,12,17)}$.

Regarding the other aspects covered in the questionnaire, such as prevention, treatment and transmission, the participants were more confident in their answers. However, incorrect answers were also marked and they deserve attention, such as the transmission of gonorrhea through the use of someone else's towels and underwear, the use of contraceptives to prevent STIS, and the use of condoms to treat these infections.

These results reinforce the need to develop educational strategies in prison settings to better clarify this population about the main characteristics of the STIs, thus favoring their prevention and interrupting the chain of transmission during intimate visits.

In Brazil, the epidemiological situation of the STIs and their complications are not well known, due to the fact that most of these diseases do not have compulsory notification ${ }^{(18)}$. This situation makes prevention and control actions more difficult, besides increasing its incidence in the country.

In prison settings, this scenario is more dramatic. Morbidity data on STIS/HIV/AIDS in Brazilian prisons is scarce and there are not enough reports to determine the real situation of the STIs in the prison system ${ }^{(10)}$.

The PP has a high risk of acquiring STIs/AIDS due to parenteral transmission, needle sharing and also unprotected sex. Intravenous drug use and homosexual activity without using condoms are practices frequently reported by this population ${ }^{(4,10-11,18)}$.

Another important aspect shown in this study is that, even though in a minority, the participants had doubts about the transmission of gonorrhea, syphilis and HPV. The lack of knowledge about how a disease is transmitted has relevant implications in terms of its prevention. 
Prevention represents a basic strategy for controlling the transmission of the STIs. For this strategy to be successful, it is important to carry out educational activities that prioritize the perception of risk, the encouragement of changes in sexual behavior, the promotion and adoption of preventive measures with an emphasis on the proper use of condoms ${ }^{(19)}$.

In the current context of the STIs in the PP, the promotion of condom use as a method of protection still remains as the main strategy of prevention policies in the country ${ }^{(18-19)}$.

It should be noted that condoms are easy to find in prison units, with regular distribution. However, despite prevention initiatives, STIs still represent a public health problem with high social and economic costs ${ }^{(19)}$.

In view of the existing failures in prevention, it is important that this population has access to appropriate treatments for each STI. These treatments also depend on a correct diagnosis, therefore, it is essential to monitor the patient through the health system, as this can prevent the practice of self-medication, facilitate adherence to treatment and prevent antimicrobial resistance.

Inadequate treatment of the STIs can result in complications. The complications include Pelvic Inflammatory Disease (PID), ectopic pregnancy, male and female infertility, cancer, abortions, prematurity, stillbirths, neonatal mortality and congenital infections ${ }^{(18)}$.

In addition to these complications, STIs can increase the risk of acquisition and transmission of HIV. Thus, any risk exposure to HIV should also be assessed as being at risk for other STIS ${ }^{(19)}$.

The study showed the complex situation of the PP regarding their knowledge about the STIs. Thus, it is important to review the health needs of this population and, in the specific case of the STIs, to offer more effective preventive and control actions.

\section{GINAL CONSIDERATIONS}

The sample of the PP participating in this study demonstrated knowledge regarding the prevention of the STIS, marking the use of condoms during sexual intercourse as an essential component to avoid transmission. The identification of the STIs illustrated in the questionnaire was hindered in situations where the manifestation of the infection was characterized by penile lesions. The forms of STI treatment generated doubts in the PP participating in this study. These doubts included both infections characterized by urethritis and those involving penile lesions. The forms of transmission of the STIs were also the target of misunderstandings, which deserve special attention as this may have an impact on preventing these infections.

The illustrated questionnaire used in this research managed to approach in an objective and contextualized way the main STIs that affect prison populations and that have clinical signs that facilitate their identification. This instrument can be used in other studies to verify the knowledge of this population on this topic and to support educational activities in prison units.

The data obtained reinforce the need for greater investments with respect to the prevention of the STIs in the prison setting. These investments should include educational activities, focusing on meaningful learning contextualized to the profile of this population, that is, young adults, with low schooling and little access to information.

In this sense, the use of the Andragogy resources can facilitate the learning process in the educational activities, since adult learning tends to be more complex due to the variables that influence it, such as teaching styles, motivation to participate, cultural issues, self-esteem, learning experiences and personal problems ${ }^{(20)}$.

Thus, the strategies used must favor significant learning, and the construction of knowledge, in addition to developing skills and attitudes, with autonomy and responsibility ${ }^{(14)}$.

A limitation of this study is that is has been carried out in a single prison unit in the state of São Paulo. However, it should be noted that for security reasons there are restrictions on access to other prison units, which makes it difficult to design a random sample of PPs from other prisons.

Another important aspect is that the sample of the PP participating in the study was composed exclusively of individuals regularly enrolled in the educational activities offered in the prison system, thus excluding a contingent of individuals who do not participate in these activities, but who are also vulnerable to STIs.

As a result of this study, it is proposed that public security agencies carry out an intensive and evidence-based compulsory notification of their own, within the Brazilian prison system, in order to obtain greater support for the implementation of health promotion and STI prevention measures. 


\section{REFERENCES}

1. Ministério da Justiça (BR). Departamento Penitenciário Nacional. Levantamento Nacional de Informações Penitenciárias INFOPEN - dezembro 2014. Brasília (DF); 2014 [cited 28 Aug 2017]. Available from: https://www.conjur.com.br/ dl/infopen-dez14.pdf

2. Ministério da Justiça e Segurança Pública. Departamento Penitenciário Nacional. Levantamento nacional de informações penitenciárias INFOPEN mulheres. 2. ed. Brasília (DF); 2017 [cited 2019 Jul 23]. Available from: http://depen.gov.br/DEPEN/ depen/sisdepen/infopen-mulheres/infopenmulheres_arte_07-03-18.pdf

3. Bezerra ATAF. HIV/Aids e demais infecções sexualmente transmissíveis em população carcerária brasileira: uma revisão sistemática [dissertação]. Teresina (PI): Fundação Oswaldo Cruz; 2015 [cited 2017 Sep 15]. p. 80. Available from: http://bvssp.icict.fiocruz.br/lildbi/docsonline/get.php?id=4520

4. Soares CLS, Spagno 0, Souza C, Lima AAM, Lima EKV. Síflis em privados de liberdade em uma unidade prisional no interior de Rondônia. Braz J Health Rev. 2019 [cited 2019 Jul 11];2(2)2195-205. Available from: http://www.brjd.com. br/index.php/BJHR/article/view/1632

5. Sevalho G. 0 conceito de vulnerabilidade e a educação em saúde fundamentada em Paulo Freire. Interface (Botucatu). 2018 [cited 2019 Dec 20];22(64):17788. Available from: http://www.scielo.br/pdf/icse/v22n64/1807-5762icse-1807-576220160822.pdf

6. Cordeiro EL, Silva TM, Silva LSR, Pereira CEA, Patrício FB, Silva CM. Perfil epidemiológico dos detentos: patologias notificáveis. Av Enferm. 2018 [cited 2019 Nov 13];36(2):170-8. Available from: http://www.scielo.org.co/pdf/aven/ v36n2/0121-4500-aven-36-02-170.pdf

7. Ministério da Saúde (BR). Secretaria de Vigilância em Saúde. Vigilância em saúde no Brasil 2003|2019: da criação da Secretaria de Vigilância em Saúde aos dias atuais. Bol Epidemiol. 2019 [cited 2019 Nov 15];50(n.esp.):1-154. Available from: http://www.rets.epsjv.fiocruz.br/biblioteca/vigilancia-emsaude-no-brasil-20032019-da-criacao-da-secretaria-de-vigilancia-em-saude

8. Brasaglini R. Do plano à política de saúde no sistema prisional: diferenciais, avanços, limites e desafios. Physis. 2016 [cited 2019 Jul 23];26(4):142939. Available from: http://www.scielo.br/pdf/physis/v26n4/1809-4481physis-26-04-01429.pdf

9. Fernandes MA et al. Infecções sexualmente transmissíveis e as vivências de mulheres em situação de reclusão. Rev Enferm UERJ. 2016 [cited 2019 Jul 23];24(6):e27774. Available from: https://www.e-publicacoes.uerj.br/index. php/enfermagemuerj/article/view/27774/21206

10. Ministério da Saúde (BR). Secretaria de Vigilância em Saúde. Departamento de Doenças de Condições Crônicas e Infecções Sexualmente Transmissíveis. Protocolo clínico e diretrizes terapêuticas para atenção integral às pessoas com infecções sexualmente transmissíveis (IST). Brasilia (DF): Ministério da Saúde; 2019 [cited 2019 Jul 23]. Available from: http://www.aids.gov.br/pt-br/pub/2015/protocoloclinico-e-diretrizes-terapeuticas-para-atencao-integral-pessoas-com-infeccoes
11. Carvalho FF. A educação em saúde como ferramenta para a prevenção de infecções sexualmente transmissíveis em pessoas privadas de liberdade [dissertação]. Marília (SP): FAMEMA; 2019.

12. Ministéro da Saúde (BR). Secretaria de Vigilância em Saúde. Departamento de DST, Aids eHepatitesvirais. Álbum seriado das IST infecções sexualmentetransmissíveis: materiais de apoio para profissionais de saúde. Brasilia (DF): Ministério da Saúde; 2016 [cited 2019 Jul 23]. Available from: http://www.aids.gov.br/pt-br/ pub/2017/album-seriado-das-infeccoes-sexualmente-transmissiveis-ist

13. Correa ME, Croda J, Castro ARCM, Oliveira SMVL, Pompilio MA, Souza RO, et al. High prevalence of treponema pallidum infection in Brazilian prisoners Am J Trop Med Hyg. 2017 [cited 2019 Jul 23];97(4) 1078-84. Available from: http://www.ajtmh.org/docserver/fulltext/14761645/97/4/tpmd170098. pdf

14. Chaves ACP, Bezerra EO, Pereira MLD, Wolfgang W. Conhecimentos e atitudes de adolescentes de uma escola pública sobre a transmissão sexual do HIV. Rev Bras Enferm. 2014. [cited 2019 Mar 4];67(1):48-53. Available from: http://www. scielo.br/pdf/reben/v67n1/0034-7167-reben-67-01-0048.pdf

15. Abreu MNS, Soares AD, Ramos DAO, Soares FV, Nunes FG, Valadão AF. Conhecimento e percepção sobre o HPV na população com mais de 18 anos da cidade de Ipatinga, (MG), Brasil. Ciênc Saúde Coletiva. 2018 [cited 2019 May 13];23(3):849-60. Available from: http://www.scielo.br/pdf/csc/v23n3/14138123-csc-23-03-0849.pdf

16. Corsino PKD, Nascimento VF, Lucieto GC, Hattori TY, Graça BC, Espinosa MM, et al. Eficácia de ação educativa com reeducandas de cadeia pública de Mato Grosso sobre o Vírus HPV. Saúde Pesqui. 2018 [cited 2019 Jul 23];11(1):11526. Available from: https://periodicos.unicesumar.edu.br/index.php/saudpesq/ article/view/6372

17. Penello AM, Campos BC, Simão MS, Gonçalves MA, Souza PMT, Salles RS, et al. Herpes genital. DST - J Bras Doenças Sex Transm. 2010 [cited 2019 Apr 13];22(2):64-72. Available from: http://pdi.sites.uff.br/wp-content/uploads/ sites/303/2018/02/r22-2-2010-3-Herpes-Genital.pdf

18. Russo K, Arreguy ME. Projeto "Saúde e Prevenção nas Escolas": percepções de professores e alunos sobre a distribuição de preservativos masculinos no ambiente escolar. Physis. 2015 [cited 2019 Apr 7];25(2):501-23. Available from: http://www.scielo.br/pdf/physis/v25n2/0103-7331physis-25-02-00501.pdf

19. Webster R, Michie S, Estcourt C, Gerressu M, Bailey JV. MenSS Trial Group. Increasing condom use in heterosexual men: development of a theory-based interactive digital intervention. Transl Behav Med. 2016;6(3):418-27. doi: https://doi.org/10.1007/s13142-015-0338-8

20. Bressiani L, Roman HR. A utilização da Andragogia em cursos de capacitação na construção civil. Gest Prod. 2017;24(4):745-62. doi: https://doi. org/10.1590/0104-530X2245-17

\section{- Corresponding author:}

Franciele Facco de Carvalho

\section{Associate editor:}

Rosana Maffacciolli 